Huang Di nei jing su wen 
This page intentionally left blank 


\title{
Huang Di nei jing su wen
}

\author{
Nature, Knowledge, Imagery \\ in an Ancient Chinese Medical Text
}

\section{Paul U. Unschuld}

WITH AN APPENDIX

The Doctrine of the Five Periods and Six Qi in the Huang Di nei jing su wen 
University of California Press

Berkeley and Los Angeles, California

University of California Press, Ltd.

London, England

(C) 2003 by the Regents of the University of California

\section{Library of Congress Cataloging-in-Publication Data}

Unschuld, Paul U. (Paul Ulrich), 1943-

Huang Di nei jing su wen : nature, knowledge, imagery in an ancient Chinese medical text, with an appendix, The doctrine of the five periods and six qi in the Huang Di nei jing su wen / Paul U. Unschuld.

p. $\mathrm{cm}$.

Includes bibliographical references and index.

ISBN 0-520-23322-O (alk. paper)

1. Su wen. 2. Medicine, Chinese-Early works to 1800 .

I. Title. [onlm: 1. Su wen. 2. Medicine, Chinese Traditional. WZ 294 s938U 2003]

R127.1.S93U57 2003

$610^{\prime} .951-\mathrm{dc} 21$

2002027170

Manufactured in the United States of America
$\begin{array}{llllllllll}12 & 11 & 10 & 09 & 08 & 07 & 06 & 05 & 04 & 03\end{array}$
$\begin{array}{lllllllll}10 & 9 & 8 & 7 & 6 & 5 & 4 & 3 & 2\end{array}$

The paper used in this publication is both acid-free and totally chlorine-free (TCF). It meets the minimum requirements of ANSI/NISO Z39.48-1992 (R 1997) (Permanence of Paper). 